\title{
A Novel Potential Therapeutic Target as Adjuvant Treatment for Cancer: The Pharmacological Interference on the $\mathrm{Ca}^{2+} /$ Camp Cellular Signaling Pathways
}

\author{
Paolo Ruggero Errante ${ }^{1}$, Alberto Andrade Leite ${ }^{1}$, Francisco Sandro Menezes-Rodrigues ${ }^{1}$, Afonso Caricati-Neto ${ }^{1}$ and Leandro \\ Bueno Bergantin ${ }^{1 *}$ \\ ${ }^{1}$ Department of Pharmacology, Universidade Federal de São Paulo, Brazil
}

"Corresponding author: Leandro Bueno Bergantin, Department of Pharmacology, Universidade Federal de São Paulo, Escola Paulista de Medicina, São Paulo, Brazil. Laboratory of Autonomic and Cardiovascular Pharmacology - Rua Pedro de Toledo, 669 - Vila Clementino, São Paulo - SP, Brazil, CEP: 04039-032,

Tel: 5511 5576-4973; E-mail: leanbio39@yahoo.com.br

Received Date: $20^{\text {th }}$ July 2017

Accepted Date: $20^{\text {th }}$ July 2017

Published Date: $30^{\text {th }}$ July 2017

Cancer is one of the leading causes of death worldwide: about 12.7 million people worldwide are diagnosed with cancer every year, and 7.6 million of the diagnosed patients die because of this disease. It is estimated that in 2030, there will be 26 million new cases, and 17 million deaths per year worldwide [1]. This number of deaths is two and a half times higher than the number of deaths worldwide caused by complications from HIV/AIDS, tuberculosis and malaria (all combined) [2]. The costs of cancer in global economy, including disability of patients, deaths and medical costs, are estimated at one trillion dollars [3], and approximately $57 \%$ of all types of cancer occur in developing countries and $43 \%$ in developed countries (excluding skin cancer) [4].

Nowadays, cancer treatment is performed through surgery, radiotherapy, chemotherapy or immunotherapy, and in many cases, it requires the combination of more than one modality of treatment [5]. Another important issue is the large number of untreated deaths, and also the pain affecting cancer patients, where most occur in developing countries [6,7]. A reduction in the annual worldwide incidence of cancer, and suffering from the disease, can be achieved by adopting: new therapeutic strategies, easy access to the treatment and lower costs. Thus, it is fundamental to understand the molecular, and cellular, mechanisms that govern the pathophysiology of cancer.

The calcium ion $\left(\mathrm{Ca}^{2+}\right)$ participates in numerous biological processes, and acts as an intracellular signalling messenger, controlling gene transcription, proliferation, differentiation and cell death. Intracellular levels of $\mathrm{Ca}^{2+}$ are regulated by plasma membrane transporters that control the influx, and efflux of $\mathrm{Ca}^{2+}$. Organelles, such as endo/sarcoplasmic reticulum, and Golgi complex, also regulate the intracellular levels of $\mathrm{Ca}^{2+}[8]$. Since tumor
Citation: Errante PR, Leite AA, Menezes-Rodrigues FS, Caricati-Neto A, Bergantin LB (2017) A Novel Potential Therapeutic Target as Adjuvant Treatment for Cancer: The Pharmacological Interference on the Ca2+/Camp Cellular Signaling Pathways. Enliven: Challenges Cancer Detect Ther 2(1): e001.

Copyright:@2017 Dr. Leandro Bueno Bergantin. This is an Open Access article published and distributed under the terms of the Creative Commons Attribution License that permits unrestricted use, distribution and reproduction in any medium, provided the original author and source are credited.

cells preferentially produce energy by anaerobic glycolysis in detrimental of mitochondrial oxidative phosphorylation process, it is necessary to pump larger amounts of $\mathrm{Ca}^{2+}$ into the intracellular compartment [9]. This can occur through the quantitative, and qualitative, alteration of $\mathrm{Ca}^{2+}$ channels and pumps in tumor cells, as transient receptor potential channels in tumors of breast, lung, liver, prostate, pancreas, colon and ovary; voltage-gated calcium channels in colon and prostate tumors; store-operated $\mathrm{Ca}^{2+}$ channels in breast tumors; plasma membrane $\mathrm{Ca}^{2+}$ - ATPases in breast and colon tumors; and store release channels in tumors of central nervous system and colorectal [10].

Another important molecule in the transduction of intracellular signals is cyclic adenosine 3', 5'-monophosphate (cAMP), which it is formed from the adenosine triphosphate (ATP), catalyzed by the enzyme adenylyl cyclase. The intracellular cAMP can activate the cAMP-dependent protein kinase, capable of phosphorylating numerous proteins, directly or indirectly controlling different cellular processes [11]. The cAMP activates protein kinase A (PKA), which alters the activity of target proteins by phosphorylating specific groups of serine and threonine. The PKA can recruit Ras protein, capable of hydrolyzing a GTP molecule in GDP [12]. The Ras-GTP combination becomes active, and propagates a cascade signal that leads to cell proliferation. Mutations of RAS gene can lead to inhibition of GTP hydrolysis by Ras proteins, causing the mutated Ras proteins reamining continuously in the active form bound to GTP, leading to disordered proliferation of tumor cells, even in the absence of stimulation by growth factors [13], such as epidermal growth factor (EGF), neuronal growth factor (NGF), platelet-derived growth factor (PDGF) and vascular endothelial growth factor (VEGF) [14]. Activation of the mutated RAS gene

\section{Enliven Archive | www.enlivenarchive.org} 2017 | Volume 2 | Issue 1 
may be associated with alterations in the regulation of the $\mathrm{Ca}^{2+}$ and cAMP signaling pathways [15], and different tumors are associated with the Ras mediated signaling pathway $[16,17]$. Once the use of $\mathrm{Ca}^{2+}$ channels blockers [18] and phosphodiesterase inhibitors (alone or in combination with other drugs) $[19,20]$ for the treatment of cancer presents significant pre-clinical results, our proposal is to pharmacologically modulate the intracellular levels of $\mathrm{Ca}^{2+}$ and cAMP signaling pathways in tumor cells [8], pathways that are altered in relation to healthy cells. Thus, we believe that combining this new strategy of treatment with existing antitumoral therapies may lead to reduce tumor progression, toxicity and costs of treatment.

\section{References}

1. Ferlay J, Soerjomataram I, Ervik M (2013) Cancer incidence and mortality worldwide: IARC CancerBase no. 11. Lyon, France: International Agency for Research on Cancer.

2. Murray CJ, Ortblad KF, Guinovart C, Lim SS, Wolock TM, et al. (2014) Global, regional, and national incidence and mortality for HIV, tuberculosis, and malaria during 1990-2013: a systematic-analysis for the Global Burden of Disease Study 2013. Lancet 384: 1005-1070.

3. John R and Ross H (2010) The global economic cost of cancer. American Cancer Society and the LIVESTRONG Organization.

4. Fidler MM, Bray F, Soerjomataram I (2017) The global cancer burden and human development: A review. Scand J Public Health 1: 1403494817715400 .

5. DeSantis CE, Lin CC, Mariotto AB, Siegel RL,Stein KD, et al. (2014) Cancer treatment and survivorship statistics. CA Cancer J Clin 64: 252271.

6. Brant JM, Newton S, Maurer MA (2017) Pain management in the middle east: Building capacity with global partners. Oncol Nurs Forum 44: 403405.

7. Gunnarsdottier S, Sigurdardottir V, Kloke M, Radbruch L, Sabatowski R et al. (2017) A multicenter study of atitudinal barriers to cancer pain management. Support Care Cancer.

8. Errante PR, Menezes-Rodrigues FS, Leite AA, Caricati-Neto A, Bergantin LB (2017) New antitumoral pharmacological strategies involving Ca2+/ cAMP signaling pathways. J Cancer Epidemiol Prevent. 2: 1.
9. Danhier P, Banski P, Payen VL, Grasso D, Ippolito L et al. (2017) Cancer metabolism in space and time: Beyond the Warburg effect. Biochim Biophys Acta. 1858: 556-572.

10. Monteith GR, Davis FM, Roberts-Thomson SJ (2012) Calcium channels and pumps in cancer: changes and consequences. J Biol Chem 287: 31666-31673.

11. Sapio L, Gallo M, Illiano M, Chiosi E, Naviglio D et al. (2017) The natural cAMP elevating compound forskolin in cancer therapy: is it time? J Cell Physiol 232: 922-927.

12. Caretta A, Mucignat-Caretta C (2011) Protein kinase A in cancer. Cancers 3: $913-926$

13. Maertens O, Cichowski K (2014) An expanding role for RAS GTPase activating proteins (RAS GAPs) in cancer. Adv Biol Regul 55: 1-14.

14. Barbara V. Silva, Bruno A. C. Horta,Ricardo Bicca de Alencastro, Angelo C. Pinto (2009) Kinase protein: structural features and chemical inhibitors. Quim 32: 453-462.

15. Idevall-Hagren O, Jakobsson I, Xu Y, Tengholm (2013) A Spatial control of Epac activity by cAMP and Ca2+-mediated activation of Ras in pancreatic $\beta$ cells. Sci Signal 6: 1-11.

16. Mahapatra DK, Asati V, Bharti SK (2017) MEK inhibitors in oncology: a patent review (2015-present). Expert Opin Ther Pat 19: 887-906.

17. Matsubayashi H, Takaori K, Morizane C, Maguchi H, Mizuma M et al. ( 2017) Familial pacreatic cancer: Concept, management and issues. World J Gastroenterol 23: 935-948.

18. Zhang Y, Cruckshanks N, Yuan F, Wang B, Pahuski M et al. (2017) Targetable T-type calcium channels drive glioblastoma. Cancer Res 77: 3479-3490

19. Yeo CD, Kim YA, Lee HY,Kim JW, Kim SJ et al. (2017) Roflumilast treatment inhibits lung carcinogenesis in benzo(a)pyrene-induced murine lung cancer model. Eur J Pharmacol 17: 30450-8.

20. Ramezani S, Vousooghi N, Kapourchali FR, Hadjighasem M, Hayat P et al. (2017) Rolipram potentiates bevacizumab-induced cell death in human glioblastoma stem-like cells. Life Sci 173: 11-19.

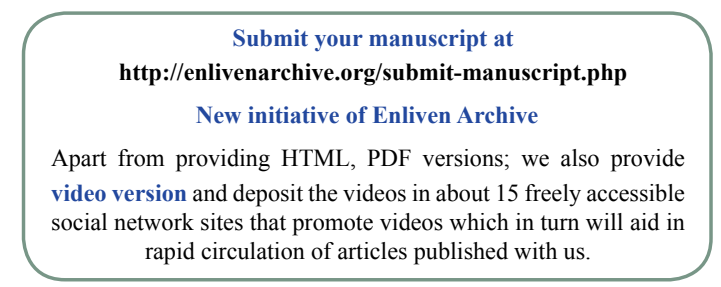

